\title{
Effects of common carp and African catfish on plankton, periphyton, benthic macroinvertebrates in pond ecosystem
}

\author{
E. R. Chirwa ${ }^{1,2, *}$, A. Mtethiwa ${ }^{1}$, W. L. Jere ${ }^{1}$, D. Kassam ${ }^{1}$ \\ ${ }^{1}$ Department of Aquaculture \& Fisheries Science, Africa Centre of Excellence in Aquaculture and Fisheries (AquaFish), \\ Lilongwe University of Agriculture \& Natural Resources (LUANAR), PO Box 219, Lilongwe, Malawi \\ ${ }^{2}$ Department of Fisheries \& Aquatic Sciences, Mzuzu University, P/Bag 201, Mzuzu, Malawi
}

\begin{abstract}
As the common carp Cyprinus carpio and African catfish Clarias gariepinus affect biotic assemblages in aquatic ecosystems through their benthivory, their introduction has been considered an environmental concern. We compare the effects of common carp and African catfish on adjacent trophic level assemblages of plankton, periphyton, benthic macroinvertebrates and native tilapia in a pond ecosystem at the National Aquaculture Center, Zomba, Malawi. Four treatments were involved in the study: ponds with common carp (T1), ponds with African catfish (T2), ponds with both common carp and African catfish (T3), and ponds lacking both common carp and African catfish (T4). In all treatments, the endemic Shire tilapia Oreochromis shiranus was also present as part of the local macrofauna. Results showed that T1 had the most abundant phytoplankton but the lowest periphyton, zooplankton and benthic macroinvertebrate abundance and diversity. T4 had the least phytoplankton but the most abundant and diverse zooplankton, periphyton and benthic macroinvertebrates. There was no significant difference between T2 and T3 (both intermediate to T1 and T4) in terms of phytoplankton, periphyton and benthic macroinvertebrate abundance and diversity. Better water quality regime and increased biomass of native tilapia fish were observed in T3 ponds. We conclude that the farming of common carp in aquatic ecosystems containing African catfish may not adversely affect the environment and that the polyculture of African catfish and common carp can be adopted as a management strategy to mitigate the potential adverse effects of common carp.
\end{abstract}

KEY WORDS: Plankton · Periphyton $\cdot$ Benthic macroinvertebrate $\cdot$ Common carp $\cdot$ African catfish

\section{INTRODUCTION}

Benthivorous fish play an important role in shaping biotic assemblages through trophic effects and sediment resuspension (Nieoczym \& Kloskowski 2014). Different studies have examined the influence of benthivorous fish on biotic assemblages of adjacent trophic levels such as plankton, periphyton and benthic macroinvertebrates, using comparisons of the assemblages with fish density (or presence/absence). Such studies have shown an increase in the abundance of phytoplankton in presence of benthivorous

\footnotetext{
*Corresponding author: erchirwa@gmail.com
}

fish (Chumchal \& Drenner 2004) and a decrease in the abundance of nektonic and benthic macroinvertebrates (Badiou et al. 2011, Nieoczym \& Kloskowski 2014) and periphyton (Tapia \& Zambrano 2003). However, most of these studies have not taken into consideration the comparative effects of multiple different benthivorous fish species on these biotic assemblages. It is reported that effects of benthivorous fish species on biotic assemblages are both ecosystem (Bajer et al. 2015) and species dependent (Rahman 2015).

The common carp Cyprinus carpio Linnaeus and African catfish Clarias gariepinus Burchell are widely

(C) The authors 2019. Open Access under Creative Commons by Attribution Licence. Use, distribution and reproduction are unrestricted. Authors and original publication must be credited. Publisher: Inter-Research · www.int-res.com 
introduced and distributed worldwide (Badiou et al. 2011, Kadye 2011). Both of these benthic fishes are reported to cause ecological changes to the biotic assemblages of organisms occupying adjacent trophic levels of the freshwater ecosystems to which they are introduced (Titus et al. 2004, Kadye 2011). As these ecological changes have the potential to affect fish production through alterations to the primary production and energy transfer efficiencies, common carp and African catfish are both listed among the world's most harmful alien species (Krishnakumar et al. 2011, Kulhanek et al. 2011). Some countries ban the introduction of common carp but grow African catfish (e.g. Malawi; Msiska \& Costa-Pierce 1993). Other countries ban the introduction of African catfish but grow common carp (e.g. India; Dhawan \& Kaur 2001). Countries that ban the introduction of common carp regard the carp as more damaging to aquatic biotic assemblages, whereas countries that ban African catfish consider this species to be more disruptive. The question of whether these 2 benthivorous fishes have similar effects on the abundance and biodiversity of organisms in adjacent trophic levels can aid in decision-making on whether countries are justified in banning one or the other. Very little information is available concerning comparative effects of the non-native common carp and the native benthic fishes on aquatic ecosystems in spite of their similar benthic feeding behaviour (Fischer et al. 2013). This study evaluates the relative effects of common carp and African catfish on plankton, periphyton and benthic macroinvertebrates in a freshwater pond ecosystem.

\section{MATERIALS AND METHODS}

\subsection{Research design and experimental units}

The study was conducted at the National Aquaculture Centre (NAC), Zomba, Malawi (15⒈ $17^{\prime} 0^{\prime \prime} \mathrm{S}$, $35^{\circ} 24^{\prime} 0 " \mathrm{E}$ ) for 5 mo (June-October 2018). Four treatments were involved; T1: Shire tilapia Oreochromis shiranus + common carp; T2: Shire tilapia + African catfish; T3: Shire tilapia + common carp + African catfish; T4: Shire tilapia only (control).

Shire tilapia ( locally 'makumba', hereafter referred to as 'tilapia') is a phytophagous tilapia endemic to Malawi and widely distributed in the country's natural waters. As it feeds on phytoplankton, the effects of carp and/or African catfish on plankton and other biotic components may also affect it. The treatments were arranged in a Completely Randomised
Design (CRD). Each treatment was replicated 3 times. Ponds were used as experimental units. Results from small-scale aquatic mesocosm experiments spanning a volumetric range of 41 to whole ponds can be extrapolated to larger, more natural aquatic systems (Spivak et al. 2010). The treatments were allocated to ponds using simple random technique. Pre-existing shallow drainable earthen ponds $(10 \times 20 \times 1 \mathrm{~m})$ were used. Before starting the experiment, all ponds were completely drained, cleared of aquatic plants and fish and exposed to the sun for $7 \mathrm{~d}$ to dry. After drying, the ponds were filled to $1 \mathrm{~m}$ depth with water from Domasi stream through a canal and left to mature for $14 \mathrm{~d}$ before stocking them with fish.

\subsection{Fish stocking and data collection}

1200 adult tilapia (mean \pm SD; $57.16 \pm 23.63 \mathrm{~g}$ body weight $[\mathrm{BW}] ; 14.3 \pm 2.09 \mathrm{~cm}$ total length [TL]) were stocked in experimental ponds on 23 April 2018 at a sex ratio of 1:3 (male:female) and at a density of 0.5 fish $\mathrm{m}^{-2}$ in $\mathrm{T} 1$ and $\mathrm{T} 2,0.2$ fish $\mathrm{m}^{-2}$ in $\mathrm{T} 3$ and 0.8 fish $\mathrm{m}^{-2}$ in T4. A week later (30 April), 360 catfish (195.88 $\pm 33.75 \mathrm{~g} \mathrm{BW}$ and $31.8 \pm 3.5 \mathrm{~cm}$ TL) and 360 carp (196.63 $\pm 52.24 \mathrm{~g}$ BW and $22.7 \pm 2.9 \mathrm{TL})$ were added to the ponds. Carp were added to ponds in T1 and T3 whereas catfish were stocked in T2 and T3 at the same stocking rate $\left(0.3\right.$ fish $\left.\mathrm{m}^{-2}\right)$, sex ratio (1:1) and biomass (589 kg ha ${ }^{-1}$ for carp; $588 \mathrm{~kg} \mathrm{ha}^{-1}$ for catfish). The stocking biomass used was the maximum natural biomass observed for carp in the wild (Crivelli 1983). The fishes were not exogenously fed during the experimental period to allow for natural feeding behaviour. Abundance and biodiversity data were collected on plankton, periphyton and benthic macroinvertebrates once every month between 09:00 and 14:00 h on each sampling day. Monthly environmental measurements were conducted on-site for the following water-quality parameters: temperature, $\mathrm{pH}$, dissolved oxygen (DO), Secchi disk depth $\left(\mathrm{Z}_{\mathrm{SD}}\right)$ and turbidity. A Secchi disk was used to measure Secchi disk depth, whereas the other parameters were measured using portable water quality checkers (Hanna Instruments, models HANNA HI 9146 for DO, HANNA HI 9125 for pH, HANNA HI 99300 for temperature and HANNA HI 98703 for turbidity). Water samples for phosphate $\left(\mathrm{PO}_{4}{ }^{3-}\right)$ determination were transported to the Central Government Water Laboratory in Lilongwe where the parameter was measured according to standard methods (APHA 2005). Fish biomass data were collected during harvesting at the end of the experiment. The data were recorded in spreadsheets (Excel 2013, 
Microsoft). Mean ( \pm SD) of each parameter was calculated for each treatment.

\subsection{Plankton enumeration}

Plankton samples were collected from 4 random stations in each pond, $2 \mathrm{~m}$ away from the pond dyke, and homogenized into 1 sample per pond according to APHA (2005). The samples were collected using a plankton net - a cone-shaped, silk bolted cloth net of fine mesh size $(20 \mu \mathrm{m}), 25 \mathrm{~cm}$ mouth diameter, $60 \mathrm{~cm}$ length, with a $27 \mathrm{ml}$ concentration bottle attached. A vertically integrated water sample was collected at each sampling station by hand-towing the plankton net vertically from about $50 \mathrm{~cm}$ deep upwards. The collected plankton samples were transported in $250 \mathrm{ml}$ dark brown glass bottles to the NAC laboratory where they were immediately analysed or preserved in $5 \%$ buffered formalin and stored for later analysis. Counting and identification of organisms was done under ordinary light microscope (model XS2-107T) according Lackey's Drop Counting technique (Lackey 1938, APHA 2005, Sontakke \& Mokashe 2014). For each pond, density of plankton was recorded as mean number of plankton individuals per liter of water (ind. $\mathrm{l}^{-1}$ ). Plankton were identified to genus level according to Prescott (1977) and APHA (2005).

\subsection{Chlorophyll a determination}

Chlorophyll a $(\mathrm{chl} \mathrm{a})$ is an important photosynthetic pigment in phytoplankton communities and a useful estimator of phytoplankton standing crop (Bhalali et al. 2013). Water samples were collected by using discrete grab sampling technique at $30 \mathrm{~cm}$ depth and $2 \mathrm{~m}$ away from the pond dyke using a 21 polythene bottle attached to a bamboo handle (APHA 2005). The samples were transported to the NAC laboratory in an iced cooler box for immediate processing and analysis. For determination of chl a concentration, samples were shaken and a $60 \mathrm{ml}$ volume of sample water was filtered using a vacuum filtration pump and $47 \mathrm{~mm} \mathrm{GF/F} \mathrm{filter.} \mathrm{Thereafter,} \mathrm{the} \mathrm{filter} \mathrm{was} \mathrm{pul-}$ verized with $90 \%$ acetone using a tissue grinder to extract chlorophyll pigment. The resulting mixture was centrifuged at $\sim 1000 \times g$ for $10 \mathrm{~min}$ (centrifuge model H-11n) and the supernatant was poured into a glass cuvette with $1 \mathrm{~mm}$ light path. The optical density (absorbance) was read at 630, 645, 663 and $750 \mathrm{~nm}$ using a Jenway spectrophotometer (model
6300) and results were corrected for phaeopigments by acidification. Chl a concentration $\left(\mathrm{mg} \mathrm{l}^{-1}\right)$ was calculated for each pond according to the equation reported in SCOR-UNESCO (1966).

\subsection{Sampling and enumeration of periphyton}

Periphyton was collected by scraping two $1 \times 1 \mathrm{~cm}$ (i.e. $1 \mathrm{~cm}^{2}$ ) units from the surface of the bamboo poles at 25, 50 and $75 \mathrm{~cm}$ depth using a scalpel blade delimited by a $1 \mathrm{~cm}^{2}$ template. Bamboo culms $(5.5 \mathrm{~cm}$ diameter) were procured from a local market and cut into $1.5 \mathrm{~m}$ poles which were vertically staked into the ponds to serve as periphyton substrates (Keshavanath et al. 2001). Five bamboo poles were staked in each pond, 1 pole at each corner of the pond and 1 at the outlet of the pond. One bamboo pole was used for each pond per month. The scraped material from the 3 depths of each bamboo pole was placed on petri dishes, pooled into 2 composite samples. The samples were resuspended in $50 \mathrm{ml}$ distilled water and preserved in $5 \%$ buffered formalin in sealed plastic vials. One of the 2 composite samples was used for the count and identification of phytoperiphyton. After thoroughly shaking the vial, a drop was sucked from it with a glass dropper and carefully placed on the microscope mechanical stage. Periphyton was counted by using Lackey's drop counting technique and recorded as mean number of individuals per $\mathrm{cm}^{2}$ (ind. $\mathrm{cm}^{-2}$ ) for each pond (Lackey 1938, APHA 2005, Sontakke \& Mokashe 2014). The periphyton organisms were identified to genus level according to Prescott (1977) and APHA (2005). The other composite sample was used for periphyton dry matter (DM) determination as an index of total periphyton biomass. Following APHA (2005), the sample was placed on pre-weighed pieces of aluminium foil, dried at $105^{\circ} \mathrm{C}$ (Isuzu drying oven model AT-E58) until constant weight and kept in a desiccator until weighed using analytical balance (model HR-120, precision $0.1 \mathrm{mg}$ ). DM was recorded for each pond as $\mathrm{mg} \mathrm{l}^{-1}$.

\subsection{Sampling and enumeration of benthic macroinvertebrates}

Benthic macroinvertebrates were collected from 3 locations in each pond: the outlet, middle and inlet of the pond. The bottom sediment samples were collected using a Ponar grab sampler $(23 \times 23 \mathrm{~cm})$ and screened in the field using a set of sieves of mesh sizes $2 \mathrm{~mm}, 1 \mathrm{~mm}$ and $0.5 \mathrm{~mm}$. The organisms re- 
tained on the sieve were carefully poured into a white enamel tray and sorted with forceps into different groups. The organisms were then carefully placed into labeled wide-mouth plastic containers and preserved in $4 \%$ buffered formalin for detailed examination and counting in the NAC laboratory. In the laboratory, samples were washed in a $0.5 \mathrm{~mm}$ mesh sieve to remove formalin. Using a binocular dissecting microscope, the organisms were counted and identified to at least order level according to keys of Macan (1959) and APHA (2005). Mean densities (ind. $\mathrm{ml}^{-2}$ ) of the different taxonomic groups were determined for each pond according to the procedure of Elliott (1977).

\subsection{Biodiversity analysis of plankton, periphyton and benthic macroinvertebrates}

The analysis of plankton, periphyton and benthic macroinvertebrate biological diversity was focused on the lowest taxonomic level to which the organisms were identified. Magurran (2004) defines biological diversity as consisting of 2 components: the number of taxa (richness) and how equally abundant the taxa are (evenness), both of which are important metrics in the evaluation of habitat integrity. Based on counts data, the Shannon-Wiener biodiversity index $\left(H^{\prime}\right)$ was computed using Paleontological Statistics (PAST) software version 3 (Hammer et al. 2001).

\subsection{Statistical analysis}

Data exploration and analysis was performed with R (version 3.5.0, R Core Team 2018). A Shapiro-Wilk test was used to test the data for normality whereas a Fligner-Killeen test was used to test the data for homoscedasticity. As most data did not meet the as- sumptions for the application of ANOVA, the data were tested for significant differences by using the nonparametric Kruskal-Wallis rank sum test $(\alpha=$ 0.05). A significant Kruskal-Wallis test was followed with a non-parametric Dunn's post hoc test for multiple comparisons $(\alpha=0.05)$. To test for the effects of time and treatment by time interactions, profile analyses were carried out $(\alpha=0.05)$. A MannWhitney $U$ test was used to test for significant differences of common carp and African catfish biomasses between their respective treatments $(\alpha=0.05)$.

\section{RESULTS}

\subsection{Water quality and fish biomass}

\subsubsection{Water quality}

Temperature ranged from 25.1 to $29.5^{\circ} \mathrm{C} ; \mathrm{pH}: 5$ to 8.5; DO: 5 to $9.1 \mathrm{mg} \mathrm{l}^{-1}$; Secchi disk depth: 12 to 42

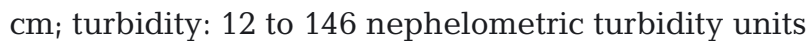
(NTU); phosphate: 0.004 to $0.147 \mathrm{mg} \mathrm{l}^{-1}$. Temperature did not differ significantly between treatments $(p>0.05)$ (Table 1). Other water-quality conditions differed significantly between treatments $(\mathrm{p}<0.001)$, with Secchi disk depth, dissolved oxygen and $\mathrm{pH}$ being highest in T4 and lowest in T1. Turbidity and phosphates were highest in T1 and lowest in T4. T3 had water-quality conditions that were intermediate between T1 and T4. There were no significant differences between T2 and T3 $(p>0.05)$ in terms of the water-quality conditions.

\subsubsection{Fish biomass}

Fish biomass increased for all fish species over the experimental period (Table 2). Average biomass

Table 1. Water-quality parameters (Kruskal-Wallis $H$-values and mean $\pm \mathrm{SD}$ ) in experimental ponds under different treatment regimes. T1: ponds stocked with carp; T2: ponds stocked with catfish; T3: ponds stocked with carp + catfish; T4: ponds containing neither carp nor catfish (control). Ponds also contained the native Shire tilapia. Temp: temperature; $Z_{\mathrm{SD}}$ : Secchi disk depth; DO: dissolved oxygen; $\mathrm{PO}_{4}{ }^{3-}$ : phosphate. Values with the same superscript in a row are not significantly different at $\alpha=0.05$

\begin{tabular}{|c|c|c|c|c|c|c|c|}
\hline & \multirow{2}{*}{ Unit } & \multicolumn{4}{|c|}{ Treatment } & \multirow{2}{*}{$H$-value } & \multirow{2}{*}{$\mathrm{p}$} \\
\hline & & $\mathrm{T} 1$ & $\mathrm{~T} 2$ & T3 & $\mathrm{T} 4$ & & \\
\hline Temp & ${ }^{\circ} \mathrm{C}$ & $25.4 \pm 2.8^{\mathrm{a}}$ & $25.6 \pm 3.0^{\mathrm{a}}$ & $25.5 \pm 2.8^{\mathrm{a}}$ & $25.4 \pm 3.1^{\mathrm{a}}$ & 1.287 & 0.732 \\
\hline $\mathrm{Z}_{\mathrm{SD}}$ & $\mathrm{cm}$ & $13.9 \pm 1.7^{\mathrm{a}}$ & $22.3 \pm 4.9^{\mathrm{b}}$ & $20.7 \pm 3.2^{\mathrm{b}}$ & $33.5 \pm 5.8^{\mathrm{c}}$ & 181.8 & $<0.001$ \\
\hline Turbidity & NTU & $132 \pm 18^{\mathrm{a}}$ & $83 \pm 38.2^{b}$ & $84.8 \pm 8.3^{\mathrm{b}}$ & $25.8 \pm 7.9^{c}$ & 166.7 & $<0.001$ \\
\hline DO & $\mathrm{mg} \mathrm{l}^{-1}$ & $5.7 \pm 0.55^{\mathrm{a}}$ & $6.7 \pm 0.81^{b}$ & $6.58 \pm 0.3^{\mathrm{b}}$ & $7.45 \pm 0.8^{\mathrm{c}}$ & 116.7 & $<0.001$ \\
\hline $\mathrm{pH}$ & Unitless & $5.9 \pm 0.34^{\mathrm{a}}$ & $6.9 \pm 0.43^{b}$ & $6.61 \pm 0.4^{\mathrm{b}}$ & $8.04 \pm 0.6^{\mathrm{c}}$ & 185.6 & $<0.001$ \\
\hline $\mathrm{PO}_{4}{ }^{3-}$ & $\mathrm{mg} \mathrm{l}^{-1}$ & $0.12 \pm 0.01^{\mathrm{a}}$ & $0.08 \pm 0.01^{\mathrm{b}}$ & $0.09 \pm 0.01^{b}$ & $0.04 \pm 0.01^{\mathrm{c}}$ & 170.8 & $<0.001$ \\
\hline
\end{tabular}


Table 2. Fish biomass $\left(\mathrm{kg} \mathrm{ha}^{-1}\right)$ in experimental ponds under different treatments (see Table 1). Superscripts with the same letter in a row indicate no significant difference at $\alpha=0.05 . H=$ Kruskal-Wallis test statistic; $M-W U=$ Mann-Whitney $U$ test statistic. -: not applicable

\begin{tabular}{|c|c|c|c|c|c|c|c|}
\hline \multirow{2}{*}{ Species } & \multirow[t]{2}{*}{ Period } & \multicolumn{4}{|c|}{ - Treatment } & \multirow[t]{2}{*}{ Statistic } & \multirow{2}{*}{$\mathrm{p}$} \\
\hline & & $\mathrm{T} 1$ & $\mathrm{~T} 2$ & T3 & $\mathrm{T} 4$ & & \\
\hline \multirow[t]{3}{*}{ Tilapia } & At stocking & $287.1^{\mathrm{a}}$ & $282.2^{\mathrm{a}}$ & $132.8^{\mathrm{b}}$ & $471.5^{\mathrm{c}}$ & $H=155.3$ & $<0.001$ \\
\hline & At harvest & $294.0^{\mathrm{a}}$ & $297.3^{\mathrm{a}}$ & $141.2^{\mathrm{b}}$ & $485.2^{\mathrm{c}}$ & $H=149.7$ & $<0.001$ \\
\hline & Increase (\%) & 2.3 & 5.3 & 6.3 & 2.9 & - & - \\
\hline \multirow[t]{3}{*}{ Carp } & At stocking & 589.3 & - & 588.6 & - & $\mathrm{M}-\mathrm{W} U=32.5$ & 0.197 \\
\hline & At harvest & 966.1 & - & 959.4 & - & $\mathrm{M}-\mathrm{W} U=18.5$ & 0.018 \\
\hline & Increase (\%) & 69.0 & - & 69.7 & - & - & - \\
\hline \multirow[t]{3}{*}{ Catfish } & At stocking & - & 587.9 & 588.3 & - & $\mathrm{M}-\mathrm{W} U=24.2$ & 0.269 \\
\hline & At harvest & - & 599.2 & 597.6 & - & $\mathrm{M}-\mathrm{W} U=37.1$ & 0.174 \\
\hline & Increase (\%) & - & 1.9 & 1.5 & - & - & - \\
\hline
\end{tabular}

increase was highest for common carp (69\%) and lowest for African catfish (2\%) over the experimental period. Tilapia biomass increased by an average of $4 \%$ from time of stocking to harvest, with greatest increase recorded in tilapia grown in polyculture with both common carp and African catfish (T3). Biomass of common carp at harvest was significantly lower when it was grown with African catfish than when it was grown separately from African catfish $(\mathrm{p}=0.018)$. On the other hand, biomass of African catfish did not significantly change whether or not it was grown together with common carp $(\mathrm{p}=0.174)$.

\subsection{Phytoplankton abundance and composition}

Principal component analysis (PCA) showed that phytoplankton abundance accounted for $87.37 \%$ of the variations in the abundance of zooplankton, periphyton and benthic macroinvertebrates. Only $0.0018 \%$ of the variations in abundance of zooplankton, periphyton and benthic macroinvertebrates was explained by tilapia biomass, indicating that tilapia did not significantly contribute to variations in these organisms. A total of 1092 individuals of phytoplankton belonging to 21 genera and 4 classes $(63.0 \%$ Cyanophyceae, 23.0\% Chlorophyceae, 13.4\% Bacil-
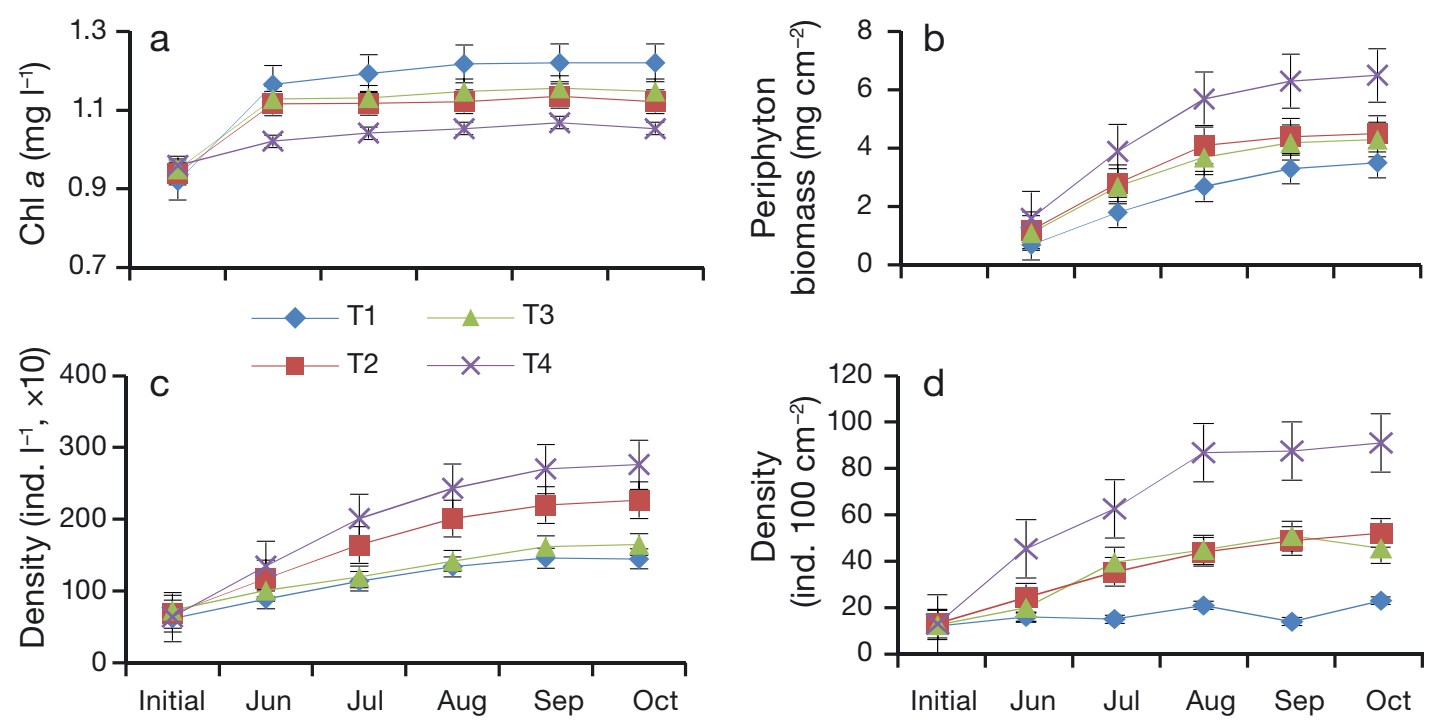

Fig. 1. Temporal trends of (a) phytoplankton biomass as chl $a_{1}$ (b) periphyton dry matter biomass, (c) zooplankton density, and (d) benthic macroinvertebrate density in the experimental ponds under 4 different treatments (see Table 1). Data are mean $\pm \mathrm{SE}$ 
lariophyceae, $0.6 \%$ Xanthophyceae) were found at the study site. Mean $( \pm \mathrm{SD})$ density (ind. $\left.\mathrm{l}^{-1}\right)$ and biomass (chl $a_{i} \mathrm{mg} \mathrm{l}^{-1}$ ) of phytoplankton varied significantly among treatments $(p<0.001)$, being highest in $\mathrm{T} 1$ and lowest in T4 (Table 3, Fig. 1a). There were no significant differences between T2 and T3 ponds in mean density $(p=0.067)$ and chl a biomass $(p=0.059)$. The genera Anabaena and Oscilatoria (Cyanophyceae) were the most abundant, accounting for over $40 \%$ of the total phytoplankton. They were more dominant in ponds containing benthic fishes and least in ponds lacking the benthic fishes. The least abundant genera were Pinnularia (Bacillariophyceae), Tribonema (Xanthophyceae), Bubochaete and Ulothrix (Chlorophyceae) and accounted for only $0.2 \%$ of the total numerical phytoplankton abundance.

\subsection{Periphython abundance and composition}

Periphyton consisted of 28 genera and 4 classes (59\% Cyanophyceae, $24 \%$ Chlorophyceae, 16\% Bacillariophyceae, $1 \%$ Xanthophyceae). Mean $( \pm \mathrm{SD})$ density (ind. $\mathrm{cm}^{-2}$ ) and dry matter biomass $(\mathrm{DM} \mathrm{mg}$ $\mathrm{cm}^{-2}$ ) of periphyton varied significantly between treatments $(\mathrm{p}<0.001)$, with T4 ponds having the highest periphyton density and DM biomass, and the least in T1 (Table 3, Fig. 1b). There were no significant differences between T2 and T3 in terms of periphyton density $(p=0.150)$ and DM biomass $(p=0.370)$. The genus Phormidium (Cyanophyceae) dominated the periphyton population, accounting for $37 \%$ of the total periphyton number and was present in all exper- imental ponds. Genera Tolypothrix (Cyanophyceae), Staurastrum (Chlorophyceae) and Tribonema (Xanthophyceae) were the least abundant, making up only $0.1 \%$ of the total periphyton population. Generally, Cyanophyceae dominated T1, T2 and T3 ponds.

\subsection{Zooplankton abundance and composition}

Zooplankton assemblage comprised 20 genera and 3 major groups (50\% rotifers, $27 \%$ copepods, $23 \%$ cladocerans). Mean $( \pm \mathrm{SD})$ zooplankton density (ind. $\mathrm{l}^{-1}$ ) varied significantly between treatments $(\mathrm{p}<$ 0.001), with T4 ponds having the most abundant zooplankton, followed by T2, T3 and T1 (Table 3, Fig. 1c). There were no significant differences between $\mathrm{T} 1$ and T3 in terms of zooplankton density $(p=0.210)$. The genera Keratella and Synchaeta (rotifers) were the most abundant in all ponds, accounting for 17 and $16 \%$, respectively, of the total number of zooplankton. The least abundant genera, constituting only $1 \%$ of total zooplankton, included the rotifer Brachionus, copepod Mesocyclops and cladocerans Polyphemus and Penilia.

\subsection{Benthic macroinvertebrate abundance and composition}

Benthic macroinvertebrates consisted of 9 families and 4 classes $(68 \%$ Insecta, $16 \%$ Hirudinea, $12 \%$ Gastropoda, $4 \%$ Oligochaeta). Density (ind. $\mathrm{cm}^{-2}$ ) of benthic macroinvertebrates differed significantly be-

Table 3. Abundance and biodiversity of plankton, periphyton and benthic macroinvertebrates (Kruskal-Wallis $H$-values and mean \pm SD) in experimental ponds under different treatments (see Table 1). DM: dry matter; $H^{\prime}$ : Shannon-Wiener diversity index. Superscripts with the same letter in a row indicate no significant difference at $\alpha=0.05$

\begin{tabular}{|c|c|c|c|c|c|c|c|}
\hline \multirow{2}{*}{\multicolumn{2}{|c|}{ Units }} & \multicolumn{4}{|c|}{ - Treatment } & \multirow{2}{*}{$H$-value } & \multirow[t]{2}{*}{$\mathrm{p}$} \\
\hline & & $\mathrm{T} 1$ & $\mathrm{~T} 2$ & T3 & $\mathrm{T} 4$ & & \\
\hline \multicolumn{8}{|c|}{ Phytoplankton } \\
\hline Density & ind. $\mathrm{l}^{-1}$ & $690 \pm 1.3^{\mathrm{a}}$ & $317 \pm 1.4^{\mathrm{b}}$ & $319 \pm 1.7^{b}$ & $125 \pm 1.3^{\mathrm{c}}$ & 43.42 & $<0.001$ \\
\hline Chl a & $\mathrm{mg} \mathrm{l}^{-1}$ & $1.04 \pm 0.01^{\mathrm{a}}$ & $1.12 \pm 0.1^{b}$ & $1.14 \pm 0.01^{b}$ & $1.05 \pm 0.2^{\mathrm{c}}$ & 51.28 & $<0.001$ \\
\hline Diversity & Shannon $H^{\prime}$ & $1.42 \pm 0.1^{\mathrm{a}}$ & $1.55 \pm 0.1^{\mathrm{b}}$ & $1.55 \pm 0.2^{\mathrm{b}}$ & $1.87 \pm 0.01^{\mathrm{c}}$ & 39.99 & $<0.001$ \\
\hline \multicolumn{8}{|c|}{ Periphyton } \\
\hline Density & ind. $\mathrm{cm}^{-2}$ & $173 \pm 3.7^{\mathrm{a}}$ & $209 \pm 8.7^{b}$ & $210 \pm 3.5^{\mathrm{b}}$ & $304 \pm 2.8^{\mathrm{c}}$ & 49.92 & $<0.001$ \\
\hline $\mathrm{DM}$ & $\mathrm{mg} \mathrm{cm}^{-2}$ & $2.4 \pm 0.25^{\mathrm{a}}$ & $3.4 \pm 0.25^{b}$ & $3.2 \pm 0.34^{\mathrm{b}}$ & $4.8 \pm 0.46^{c}$ & 49.66 & $<0.001$ \\
\hline Diversity & Shannon $H^{\prime}$ & $1.97 \pm 0.01^{\mathrm{a}}$ & $1.84 \pm 0.1^{\mathrm{b}}$ & $1.83 \pm 0.1^{b}$ & $2.22 \pm 0.01^{\mathrm{c}}$ & 52.20 & $<0.001$ \\
\hline \multicolumn{8}{|c|}{ Zooplankton } \\
\hline Density & ind. $1^{-1}$ & $115 \pm 9.2^{\mathrm{a}}$ & $186 \pm 8.4^{\mathrm{b}}$ & $138 \pm 6.6^{\mathrm{a}}$ & $225 \pm 8.3^{\mathrm{c}}$ & 46.21 & $<0.001$ \\
\hline Diversity & Shannon $H^{\prime}$ & $2.03 \pm 0.2^{\mathrm{a}}$ & $2.21 \pm 0.1^{\mathrm{b}}$ & $1.98 \pm 0.01^{\mathrm{a}}$ & $2.32 \pm 0.1^{\mathrm{c}}$ & 50.59 & $<0.001$ \\
\hline \multicolumn{8}{|c|}{ Benthic macroinvertebrates } \\
\hline Density & ind. $100 \mathrm{~cm}^{-2}$ & $14.2 \pm 0.4^{\mathrm{a}}$ & $41.6 \pm 0.5^{\mathrm{b}}$ & $40.1 \pm 0.6^{\mathrm{b}}$ & $74.7 \pm 0.4^{\mathrm{c}}$ & 50.15 & $<0.001$ \\
\hline Diversity & Shannon $H^{\prime}$ & $1.53 \pm 0.2^{\mathrm{a}}$ & $1.81 \pm 0.4^{\mathrm{b}}$ & $1.78 \pm 0.3^{\mathrm{b}}$ & $2.07 \pm 0.6^{\mathrm{c}}$ & 48.50 & $<0.001$ \\
\hline
\end{tabular}


Table 4. Treatment and time effects on the abundance of plankton, periphyton and benthic macroinvertebrates under different treatments

\begin{tabular}{|lcrrr|}
\hline Dependent variable & Fixed factor & df & $F$ & $\mathrm{p}$ \\
\hline Phytoplankton & Month & 4 & 583.17 & 0.114 \\
density & Treatment & 3 & 328.57 & $<0.001$ \\
& Month $\times$ Treatment & 12 & 10.98 & 0.088 \\
Periphyton & Month & 4 & 261.05 & 0.097 \\
density & Treatment & 3 & 108.02 & 0.016 \\
& Month $\times$ Treatment & 12 & 22.94 & 0.072 \\
Zooplankton & Month & 4 & 315.26 & 0.103 \\
density & Treatment & 3 & $278.11<0.001$ \\
& Month $\times$ Treatment & 12 & 15.08 & 0.081 \\
Benthic & Month & 4 & 178.10 & 0.192 \\
macroinvertebrates & Treatment & 3 & 96.25 & $<0.001$ \\
density & Month $\times$ Treatment & 12 & 19.44 & 0.086 \\
& & & & \\
\hline
\end{tabular}

tween treatments $(\mathrm{p}<0.001)$, with T4 ponds having the highest, and T1 ponds the lowest mean density (Table 3, Fig. 1d). There was no significant difference in density of benthic macroinvertebrates between T2 and T3 ( $p=0.143$ ). Chironomids were the most abundant, accounting for $25 \%$ of the total number of benthic macroinvertebrates recorded. Alderfly nymphs (Megaloptera) were the least abundant, constituting only $1.2 \%$ of all benthic macroinvertebrates recorded.

\subsection{Biological diversity of plankton, periphyton and benthic macroinvertebrates}

Shannon-Wiener diversity index $\left(H^{\prime}\right)$ was computed for plankton, periphyton and benthic macroinvertebrates (Table 3). Biodiversity values ranged from 1.5 to 1.9 for phytoplankton, 1.75 to 2.26 for periphyton, 1.52 to 2.45 for zooplankton and 1.15 to 2.14 for benthic macroinvertebrates. $H^{\prime}$ values were highest in T4 and lowest in T1 ponds $(\mathrm{p}<0.001)$ for phytoplankton, periphyton, zooplankton and benthic macroinvertebrates (Table 1). There were no significant differences in $H^{\prime}$ values between T2 and T3 ponds for phytoplankton $(p=0.115)$, periphyton $(p=$ $0.075)$ and benthic macroinvertebrates $(p=0.107)$. There was no significant difference in $H^{\prime}$ values between T1 and T3 for zooplankton $(p=0.094)$.

\subsection{Temporal effects}

Treatment had significant effect on the abundance of phytoplankton $(\mathrm{p}<0.001)$, periphyton $(\mathrm{p}=0.016)$, zooplankton $(\mathrm{p}<0.001)$ and benthic macroinverte- brates $(\mathrm{p}<0.001)$ (Table 4). However, time (month) did not significantly affect the abundance of phytoplankton $(\mathrm{p}=0.114)$, periphyton $(p=0.097)$, zooplankton $(p=0.103)$ and benthic macroinvertebrates $(p=0.192)$. In addition, the effects of time and treatment interactions on the abundance of these organisms were also not significant ( $p>0.05)$, indicating that there was no evidence that the effects of treatment depended on time. Thus, only the effects of treatment on periphyton, plankton and benthic macroinvertebrates were analyzed further and discussed.

\section{DISCUSSION}

Water-quality conditions measured in the experimental ponds were typical of water bodies containing common carp and African catfish (Chumchal \& Drenner 2004, Kadye 2011). Higher turbidity and phosphate concentration, accompanied by low Secchi disk depth, in ponds with common carp than in ponds with African catfish indicated that carp caused greater sediment resuspension than African catfish. Phosphates are important nutrients in freshwater bodies and their availability in the water column caused by benthic foraging activity of fish has been associated with increased abundance of phytoplankton, which is food for phytophagous fish such as tilapia (Badiou et al. 2011). However, when common carp biomass exceeds a threshold of $500 \mathrm{~kg} \mathrm{ha}^{-1}$, tilapia growth is impaired due to excessive sediment resuspension (Lougheed et al. 1998). The increase in tilapia biomass was low in ponds with common carp and ponds without carp and catfish, but was greatest in ponds where the tilapia was grown in polyculture with both common carp and African catfish. Rahman (2015) suggests that when common carp is reared together with a stronger and more aggressive benthivorous fish, its ability to resuspend sediment is reduced and just enough nutrients and sunlight are available in the water column to promote primary production. Turbidity and phosphate content in ponds containing both carp and African catfish (T3) were lower than in ponds with carp without African catfish (T1) although they were higher than in ponds without either carp and African catfish (T4).

Plankton, periphyton and benthic macroinvertebrate abundance, composition and diversity varied significantly between treatments $(p<0.001)$. PCA showed that $87.37 \%$ of the variations in zooplankton, periphyton and benthic macroinvertebrates was explained by phytoplankton density. This is not sur- 
prising considering that phytoplankton is the basis of food chains in aquatic ecosystems (Bhalali et al. 2013). Although tilapia is phytophagous (Das et al. 2012), its density accounted for a negligible $0.0018 \%$ of the changes in plankton, periphyton and benthic macroinvertebrates.

Phytoplankton abundance was higher in ponds containing common carp and African catfish than in control ponds lacking these benthic fishes. These findings were similar to those of Chumchal \& Drenner (2004), who observed that mesocosms containing common carp had increased phytoplankton abundance compared to mesocosms where carp was absent. Kadye (2011) reported that phytoplankton biomass increased in aquatic ecosystems containing African catfish relative to water bodies where the species was not present. Through sediment resuspension, benthivorous fish increase turbidity and nutrients in the water column (Volkenborn et al. 2007). In turn, the nutrients stimulate phytoplankton growth, with the potential to cause algal bloom when in excess (Badiou et al. 2011). Higher abundance and lower diversity of phytoplankton was recorded in T1 ponds compared to T2 ponds. This reflects differences in sediment resuspension capabilities between these 2 benthic fishes. Common carp has been reported to cause greater sediment resuspension than many other fishes (Cline 1969, Parkos et al. 2003, Fischer et al. 2013).

Periphyton, zooplankton and benthic macroinvertebrates were most abundant and diverse in control ponds lacking the benthic fishes and least abundant and diverse in ponds containing common carp. Tapia \& Zambrano (2003) also found that periphyton abundance and diversity was depressed in presence of common carp. Bajer et al. (2009), Badiou et al. (2011) and Nieoczym \& Kloskowski (2014) observed that zooplankton and benthic macroinvertebrate abundance and diversity were depressed in presence of common carp. Elevated turbidity and phytoplankton density in ponds with common carp suppress periphyton by shading light penetration in the pond (Badiou et al. 2011, Mischke 2012). In addition, turbidity reduces zooplankton's and benthic macroinvertebrate's visual ability to identify prey items and mates (Matsuzaki et al. 2009). Turbidity also clogs the respiratory apparatus of fish and gill-breathing zooplankton and smothers eggs of fish and benthic macroinvertebrates (Badiou et al. 2011). Predation by fish is another cause of abundance and biodiversity losses in zooplankton and benthic macroinvertebrate communities (Miller \& Crowl 2006). Common carp primarily feeds on benthic macroinvertebrates but switches to zooplankton feeding when displaced from its benthic to limnetic feeding niche by a more aggressive benthic fish (Rahman 2015). This possible shift in carp's feeding niche could be the major reason for the lack of significant difference in abundance and biodiversity of phytoplankton, periphyton and benthic macroinvertebrates between ponds containing African catfish and those stocked with both common carp and African catfish.

Loss of submerged vegetation such as periphyton and submerged macrophytes due to light shading has also been implicated in the reduction of zooplankton and benthic macroinvertebrate abundance and biodiversity due to loss of habitat (Mischke 2012). Furthermore, the filamentous blue-green algae that dominated ponds stocked with benthic fishes, particularly common carp, are not readily edible by zooplankton, and they produce cyanotoxins which are toxic to fish, zooplankton and benthic macroinvertebrates (Dawah \& Gomaah 2005). Decomposition of dead blooms of cyanophyceae in ponds containing common carp consumes dissolved oxygen, creating inhospitable conditions for most zooplankton and benthic macroinvertebrates (Goto et al. 2012, Engström-Öst et al. 2015).

\section{CONCLUSIONS}

Both common carp and African catfish caused alterations in the abundance and biodiversity of plankton, periphyton and benthic macroinvertebrates in the freshwater pond ecosystem. Phytoplankton abundance increased, whereas the abundance of periphyton, zooplankton and benthic macroinvertebrates decreased, in presence of carp and African catfish. Further, the biodiversity of plankton, periphyton and benthic macroinvertebrates decreased. These effects are thought to be mediated mainly through sediment resuspension by the benthic fishes as they stir the mud on the bottom of the aquatic ecosystem during their feeding activity. Predation by benthic fishes on zooplankton and benthic macroinvertebrates might also have been important. Raised in separate fish ponds, common carp increased phytoplankton abundance but decreased the abundance of periphyton, zooplankton and benthic macroinvertebrates more than African catfish. Interestingly, when common carp was raised together with African catfish in the same pond, its ability to alter water quality and the abundance and biodiversity of phytoplankton, periphyton and benthic macroinvertebrates was diminished. However, zooplankton abundance and diversity decreased remarkably in 
these ponds. Thus, the addition of common carp to an ecosystem containing African catfish can decrease zooplankton abundance and diversity but may not significantly affect water quality or the abundance and biodiversity of phytoplankton, periphyton and benthic macroinvertebrates; in addition, it can lead to an improvement of the tilapia yield. We conclude that (1) the adoption of tilapia + common carp + African catfish polyculture is a good aquaculture management strategy to maximize pond fish production and mitigate the adverse effects of carp on water quality, abundance and diversity of phytoplankton, periphyton and benthic macroinvertebrates, and (2) the farming of common carp in ecosystems where African catfish naturally occurs is unlikely to adversely affect water quality, native fish, phytoplankton, periphyton and benthic macroinvertebrates.

Acknowledgements. Support for this research was made possible through a capacity building competitive grant (Grant No. RU/2016/GTA/DRG/007) 'Training the next generation of scientists' provided by Carnegie Cooperation of New York through the Regional Universities Forum for Capacity Building in Agriculture (RUFORUM). Mzuzu University complemented this with additional research funds through its Research and Publications committee.

\section{LITERATURE CITED}

APHA (2005) Standard methods for the examination of water and wastewater, 21st edn. American Public Health Association, Washington, DC

Badiou P, Goldsborough LG, Wrubleski D (2011) Impacts of the common carp (Cyprinus carpio) on freshwater ecosystems: a review. In: JD Sanders \& SB Peterson (eds) Carp: habitat, management and diseases. Nova Science Publishers, Hauppauge, NY

Bajer PG, Sullivan G, Sorensen PW (2009) Effects of rapidly increasing population of common carp on vegetative cover and waterfowl in a recently restored Midwestern shallow lake. Hydrobiologia 632:235-245

Bajer PG, Cross TK, Lechelt JD, Chizinski CJ, Weber MJ, Sorenzen PW (2015) Across-ecoregion analysis suggests a hierarchy of ecological filters that regulate recruitment of a globally invasive fish. Divers Distrib 21:500-510

Bhalali S, Hoseini SA, Ghorbani R, Kordi H (2013) Relationships between nutrients and chlorophyll a concentration in the international Alma Gol Wetland, Iran. Int J Aquat Biol 1:68-75

Chumchal MM, Drenner RW (2004) Interrelationship between phosphorus loading and common carp in the regulation of phytoplankton. Arch Hydrobiol 161:147-158

* Cline JD (1969) Spectrophotometric determination of hydrogen sulfide in natural waters. Limnol Oceanogr 14: 454-458

Crivelli AJ (1983) The destruction of aquatic vegetation by carp. Hydrobiologia 106:37-41

Das P, Mandal S, Bhagabati S, Akhtar MS, Singh SK (2012) Important live food organisms and their role in aquacul- ture. Front Aquacult 5:69-86

Dawah AM, Gomaah SA (2005) Phytoplankton dynamics in earthen ponds stocked with african catfish (Clarias gariepinus) feeding with different diets. Egyptian J Phycol 6:1-15

Dhawan A, Kaur K (2001) Clarias gariepinus in Punjab waters. Fishing Chimes 21:56

Elliott JM (1977) Some methods for the statistical analysis of samples of benthic invertebrates. Sci Publ, Vol 25. Freshwater Biological Association, Ambleside, Westmorland

Engström-Öst J, Brutemark A, Vehmaa A, Motwani NH, Katajisto T (2015) Consequences of a cyanobacteria bloom for copepod reproduction, mortality and sex ratio. J Plankton Res 37:388-398

Fischer JR, Krogman RM, Quist MC (2013) Influences of native and non-native benthivorous fishes on aquatic ecosystem degradation. Hydrobiologia 711:187-199

Goto D, Lindelof K, Fanslow DL, Ludsin SA and others (2012) Indirect consequences of hypolimnetic hypoxia on zooplankton growth in a large eutrophic lake. Aquat Biol $16: 217-227$

Hammer Ø, Harper DAT, Ryan PD (2001) PAST: paleontological statistics software package for education and data analysis. Palaeontol Electron 4. https://palaeo-electronica.org/2001_1/past/issue1_01.htm

Kadye WT (2011) Assessing the impacts of invasive nonnative African sharptooth catfish Clarias gariepinus. PhD thesis. University of Rhodes, Grahamstown

Keshavanath P, Gangadhar B, Ramesh TJ, van Rooij JM and others (2001) Use of artificial substrates to enhance production of freshwater herbivorous fish in pond culture. Aquacult Res 32:189-197

Krishnakumar K, Ali A, Pereira B, Raghavan R (2011) Unregulated aquaculture and invasive alien species: a case study of the African catfish Clarias gariepinus in Vembanad Lake (Ramsar Wetland), Kerala, India. J Threat Taxa 3:1737-1744

Kulhanek SA, Ricciardi A, Leung B (2011) Is invasion history a useful tool for predicting the impacts of the world's worst aquatic invasive species? Ecol Appl 21:189-202

Lackey JB (1938) The manipulation and counting of river plankton and changes in some due to formalin preservation. Public Health Rep 53:2080-2093

Lougheed VL, Crosbie B, Chow-Fraser P (1998) Predictions on the effect of common carp (Cyprinus carpio) exclusion on water quality, zooplankton, and submergent macrophytes in a Great Lakes wetland. Can J Fish Aquat Sci 55:1189-1197

Macan TT (1959) A guide to freshwater invertebrate animals. Longman, London

Magurran AE (2004) Measuring biological diversity. Blackwell Publishing, Oxford

Matsuzaki SS, Usio N, Takamura N, Washitani I (2009) Contrasting impacts of invasive engineers on freshwater ecosystems: an experiment and meta-analysis. Oecologia 158:673-686

Miller SA, Crowl TA (2006) Effects of common carp (Cyprinus carpio) on macrophytes and invertebrate communities in a shallow lake. Freshw Biol 51:85-94

Mischke CC (ed) (2012) Aquaculture pond fertilization: impacts of nutrient input of production. John Wiley \& Sons, New York, NY

Msiska OV, Costa-Pierce BA (eds) (1993) History, status and future of common carp (Cyprinus carpio L.) as an exotic species in Malawi. WorldFish Center - ICLARM, Manila

Nieoczym M, Kloskowski J (2014) Responses of epibenthic 
and nektonic macroinvertebrate communities to a gradient of fish size in ponds. J Limnol 74:50-62

Parkos JJ III, Santucci VJ Jr, Wahl DH (2003) Effects of adult common carp (Cyprinus carpio) on multiple trophic levels in shallow mesocosms. Can J Fish Aquat Sci 60: 182-192

Prescott GW (1977) The fresh water algae. WMC Brown Company Publishers, Dubuque, IA

R Core Team (2018) R: a language and environment for statistical computing. R Foundation for Statistical Computing, Vienna. www.r-project.org

Rahman MM (2015) Role of common carp (Cyprinus carpio) in aquaculture production systems. Front Life Sci 8:399-410

SCOR-UNESCO (1966) Determination of photosynthetic pigments in sea-water UNESCO Monogr Oceanogr Methodol 1. https://unesdoc.unesco.org/ark:/48223/ pf0000071612

Sontakke GK, Mokashe SS (2014) Ostracod density of two

Editorial responsibility: Victor Benno Meyer-Rochow, Oulu, Finland freshwater lakes in India. A comparative study. Indian J Appl Res 4:591-593

Spivak AC, Vanni MJ \& Mette EM (2010) Moving on up: Can results from simple aquatic mesoscosm experiments be applied across broad spatial scales? Freshwater Biology 56:279-291

Tapia M, Zambrano L (2003) From aquaculture goals to real social and ecological impacts: carp introduction in rural central Mexico. Ambio 32:252-257

Titus JE, Grisé D, Sullivan G, Stephens MD (2004) Monitoring submersed vegetation in a mesotrophic lake: correlation of two spatio-temporal scales of change. Aquat Bot 79:33-50

Volkenborn N, Hedtkamp SIC, van Beusekom JEE, Reise K (2007) Effects of bioturbation and bioirrigation by lugworms (Arenicola marina) on physical and chemical sediment properties and implications for intertidal habitat succession. Estuar Coast Shelf Sci 74:331-343

Submitted: February 14, 2019; Accepted: June 6, 2019

Proofs received from author(s): August 5, 2019 